\title{
Armed Conflicts and Violation of the Right to Life of Children in Wau, Western Bahr el Ghazal State, South Sudan
}

\author{
Justin Filbert Rugbua* Susanne Nambatya Emmanuel Tweh Friday \\ College of Humanities and Social Sciences, Kampala International University.Ggaba Road, \\ Kansanga, Kampala District, P.O Box 20000, Uganda
}

\begin{abstract}
The study focused on identifying the common grave violations committed against children, understanding the reasons why children joined armed forces and groups and assessing the effects of armed conflicts on the right to life of children in Wau, Western Bahr el Ghazal State. Simple random sampling was used for the selection of the 375 primary respondents for the study, while purposive sampling was used to determine the 30 key informants who constituted the qualitative sample. Quantitative data analysis was based on 357 questionnaires that were complete / retrieved for the study. Children in Wau, Western Bahr el Ghazal suffer from the six grave violations committed against children in the situations of armed conflict by parties to the conflict. The most common precipitant cause of recruitment and use of children by parties to the conflict in Wau, Western Bahr el Ghazal State is poverty and the obligation to generate income for their families while others associate themselves for survival or to protect their families. Other children are abducted and threatened to take part in the fighting with the opponents, which gathered a high response rate as well, among other factors which included children, being cheap, easily manipulated, and less visible to the enemies. In terms of the effects of armed conflicts on the right to life of children in Wau, Western Bahr el Ghazal state, children are the major causalities to landmines and other explosives. Due to their playful nature, they become easy victims to unexploded landmines or landmines and other explosives that have not been successfully removed. They get killed and some get injured, among other physical effects. Other effects are psychological such as trauma and fear. The paper recommends a comprehensive approach to child protection, entailing all relevant stakeholders in the country to ensure that laws and policies on the protection of children are effectively implemented and the ratified international instruments or optional protocols are adhered to. More concrete mechanisms regarding the protection of children in situations of armed conflicts can be sought from best practices elsewhere. There should be avenues in place to beef up the budget on children protection and to ensure accountability of child protection implementations or activities. Sensitization and awareness of children's rights and protection should be continuous.
\end{abstract}

Keywords: Armed Conflicts, Children, Right to Life, Violation, South Sudan

DOI: $10.7176 /$ RHSS/11-24-02

Publication date: December $31^{\text {st }} 2021$

\section{Introduction}

South Sudan is one of the sub-Saharan African Countries with active armed conflicts since its recognition as an independent state in 2011. The United Nations International Children's Emergency Fund (UNICEF) estimates that 16,000 South Sudanese children have served as child armed combatants or support staff for the armed groups and armed forces since 2013 as the country continuously collapses into ethnic violence and civil war (UNICEF, 2016). Boys are for the most part, in a lot bigger numbers than girls, utilized as soldiers during armed conflicts. Other activities children are engaged in include; conveying food or ammo, functioning as couriers, spies, preparing food, and offering sexual types of assistance (sex slaves) particularly the girls (Nyagoah, 2018). According to the United Nations Office of the Special Representative to the Secretary-General for Children and Armed Conflict, the utilization of children for demonstrations of dread, including as suicide bombers, has emerged as a peculiarity of current warfare. These functions entail great risk and hardship. At the peak of the crises, close to 72 percent (the highest proportion in the world) of South Sudanese children cannot access school and lack security (World Vision, 2019), and 2/3 of the entire child population in South Sudan are in urgent need of humanitarian assistance (UNICEF, 2019). This evidence presents us with a stark reality that thousands of children in the country miss out on their childhood. South Sudanese children begin participating in armed conflicts from as young as the age of seven (Ensor, 2013), just like children from other Sub - Saharan African countries such as Liberia, the Democratic Republic of Congo, Uganda, Sierra Leone, Mali, and Sudan to mention but a few countries, which have been reportedly using children as child soldiers (Parker et al, 2021; Mezmur, 2019).

Different studies globally have tried to provide explanations on the involvement of children in armed conflicts. Roos (2019) noted that the type of recruitment (whether forced or voluntary) may depend on structural aspects such as resources and conflict dynamics but might also change following the armed group's needs and objectives. Some children are abducted and beaten into submission as in the case of the LRA rebel group in Uganda, led by Joseph Kony, who carried out large-scale and indiscriminate forced recruitment by raiding 
homes (Beber \& Blattman, 2013). The group is responsible for the abduction of at least 20,000 Ugandan children and the displacement of over 1.9 million people in Northern Uganda between 1987 and 2006 (Human Rights Watch, 2012). Kelly, Branham, and Decker (2016) noted that the LRA group expanded across the western border of Uganda to the Democratic Republic of Congo (DRC) as well as to the north in South Sudan, and the Central African Republic (CAR) and carried out coercive and violet abductions/kidnappings. The authors also noted that children are easier to control. They can easily be indoctrinated to the rebel group's practices, compared to adults (Kelly, Braham and Decker, 2016). Kohrt et al (2016) reported that in Nepal, many former child soldiers reported joining voluntarily. This was attributed to reasons such as; the scarcity of resources in most rural parts of the country, the presence of strong political opposition groups, personal connections, and the Maoist women belief that girls were safer from sexual violence when part of the armed group than when in the community. Chen (2014) cited in Kohrt et al (2016) identified three levels of relationships between a child and a recruiter that facilitate participation in armed conflict in Myanmar. The first level of relationship is the 'Victim Coercer relationship' where children are bound to be part of the armed force through abduction or forced involvement. The second level of relationship is the 'Patron - Client relationship' where children are bound to be part of the armed force to gain access to resources and power as a result of deprivation in their present environment. The third level of relationship is the 'Comradeship relationship' which involves children participating in the armed groups voluntarily through indoctrination or as an act of revenge for killed or injured family and friends.

The 2011 Constitution of the Republic of South Sudan specifically Article 17 provides for the rights of children including the right to life, the right to be cared for by a parent or legal guardian, the right to be protected from abduction/trafficking, prohibition from child soldiers, among others. Secondly, South Sudan ratified the Convention on the Rights of the Child in January 2015 although, the Optional Protocol to the Convention on the Rights of the Child on the involvement of children in armed conflict, has not been ratified. Despite the legal provisions in place, child protection remains extremely low in the country. The conflicts in South Sudan have greatly contributed to the suffering of children. Children have experienced physical and sexual violence, psychological distress, among other forms of suffering (Deng, 2018). Due to its ethnic diversity, Wau has repeatedly suffered from ethnic violence (Tamazuj Radio, 2017). The clashes between the Dinka and Fertit and other minority tribes have taken place in Wau, since 2016, leading to widespread deaths, destruction in Wau town, and displacement of up to 150,000 people (Tamazuj Radio, 2017). Statistics on the exact number of children affected by the conflict in Wau, Western Bahr el Ghazal State are not clear, but reports have indicated that the campaign against the use of children in armed forces and armed groups in the country has enjoyed little success (UNICEF, 2015). Wau is not an exception. In other words, the situation in the country so far reflects that there is a risk that leaders, individuals, and communities may now feel that to dehumanize another is not only justifiable but also necessary for survival. This has rendered thousands of children vulnerable to human rights violations. This study focused on identifying the common grave violations committed against children (who are defined as persons under the age of 18 years, for purposes of this study) in Wau; understanding the reasons why children in Wau joined armed forces and groups, and assessing the effects of armed conflicts on the right to life of children in Wau, Western Bahr el Ghazal State. The study on armed conflicts and violation of the right to life of children in Wau, Western Bahr el Ghazalis is particularly important for South Sudan because, (i) To the government: the study is timely to provide a basis for strengthening child protection laws, (ii) To NGOs: to come up with projects that will facilitate identification and prosecution of perpetrators to violations of children's rights, (iii) To policymakers: the study will document children's experiences in times of armed conflict which will inform them in the design and response to the challenges faced by children during conflicts, (iv) To researchers and academicians: the study will contribute to the existing body of knowledge in the subject area.

\section{Effects of Armed Conflicts on the Right to Life of Children}

Africa has been severally described as a continent with armed conflict and violence deep-rooted into its political, economic, and socio-cultural fabrics. The continent has for quite a long time experienced internal and external armed conflicts since the 1960s (Liebling, et al., 2010). For example, between 1987 and 2007 alone, out of 56 countries on the African continent, 20 experienced armed clashes (ibid). In every one of these contentions, there is a tremendous loss of lives, destruction of property, mass killings of individuals, and sexual violence among other human rights infringements (Breadcook, 2013). Children are suffering double tragedies both as targets and as tools of war (child soldiers). They are the primary victims of armed conflicts. It is estimated that in the last decade, more than two million children worldwide have been killed in situations of armed conflict, six million children have been permanently disabled or injured, more than two hundred and fifty thousand children have continued to be exploited as child soldiers, between eight thousand and ten thousand children have been killed or maimed every year as a result of landmines and more than 14 million children have been forcibly displaced within and outside their home countries since 2010 (UNICEF, 2019). Such numbers are significantly worrying despite efforts by governments and humanitarian agencies to protect children. 
According to Stewart (2013), an "armed conflict" is said to exist "whenever there is a resort to armed force between States or protracted armed violence between governmental authorities and organized armed groups or between such groups within a state. In South Sudan, war has been generally determined in the nation because of treacheries, imbalance in the conveyance of assets, the profound situated impression of underestimation, avoidance from unified power, and fierce bigotry for resistance (Young, 2012). However, some of these issues were adequately addressed by the signing of the Comprehensive Peace Agreement in 2005 and the independence of South Sudan in 2011 but these have transformed into much more powerful triggers for violence. The political rivalry continued into the post-Comprehensive Peace Agreement period sparking insurgencies in the aftermath of the 2010 elections that continued well into independence. The presence of leaders manipulating the conflicts for personal and political gains continues to torment the country. Currently, more militia groups are continuing to emerge yet there are still no strong institutions of resolving conflicts through peaceful means because of the existence of insurgent armed groups and a history of warfare (UN Security Council, 2015). Due to this, many civilians have fallen victim to armed conflicts.

The vulnerable nature of children in many cases exposes them to the dangerous effects of armed conflict. Machel (2000) noted that children's lives are put at risk, but they are also subject to psychological and social harm, which affects their development into adulthood. Accordingly, Doek (2014) established that every state in South Sudan is experiencing a crisis or emergency levels of food insecurity. More than half of South Sudanese internally displaced persons - the majority being children report having to go one or more days without food because violence has disrupted the farming calendar. Limited food supply does not only happen because of disrupted farming activities but also in most cases, reports showed that food aid from humanitarian agencies like the UNHCR is blocked on the way by rebel groups (UN Security Council, 2015). Unlike conflicts in other African countries where fighting is between states, armed conflicts in South Sudan are largely within the state. Children particularly girls become victims of sexual exploitation and gender-based violence as reported in Machel's study (1996). This makes their life miserable and sometimes resilient to cope up with new life after the conflict. They experience problems with trusting adults and can also have a fear of personnel dressed in army uniforms due to their previous experience. However, the way individuals and communities overcome past experiences varies from one person to another, and one culture to another. Harju (2013) reported that sexually abused girls often carry the quilt of shame and humiliation with them and can face family or entire community discrimination.

The most visible effects of armed conflict on children are the physically inflicted ones. Throughout the history of armed conflicts especially in Africa, civilian children are killed outright because of torture, firearms, bombs, and landmines. Or they sustain serious injuries and or lifelong disabilities - losing limbs, eyesight, and hearing. They are exposed to unbearable internal displacement and suffer all sorts of abuses. Kelly, Branham, and Decker (2016) noted that after being kidnapped, many Congolese children are forced to march for hours and sometimes days into the forest, they are not allowed to speak in their native languages such that their civilian identity is broken, they are not allowed to interact or bond with fellow child abductees, forced language acquisition, and language as an indication of identity, they are assigned new names, they experience killings and beatings and especially when they transgress in the group, they have no sense of stability or community beyond those they are traveling with, they are forced to forage for food in the forest and to undergo spontaneous fasting periods until the next raid, and they are assigned to a family structure where they are the lowest ranking members and are subject to beating and other abuse.

Wau in Western Bahr el Ghazal State is among the areas in South Sudan affected by conflicts because of its ethnic diversity. What tends to happen in the country is that groups get organized on an ethnic basis and or political divisions (which are largely representative of certain tribes as well). So, when fighting breaks out, people flee to their comrades for security, which brings about tensions, ethnically based grievances, and politically based narratives of fear (Ferdinand, 2014). This situation implies that in the event of any emergency, there is a danger that leaders, individuals, and communities might feel that to dehumanize another isn't only reasonable but additionally vital for endurance. South Sudanese children have indeed suffered from the adverse effects of the long-lasting conflicts within the country. Many of their parents have been killed, child labour, abuse, and maltreatment are reportedly increasing, schooling has been compromised, health-wise - a significant number of children are vulnerable to chronic diseases that mostly occur because of poor sanitation and lack of access to hygiene facilities in the camps, among other violations of the rights of the children (Deng, 2018; Perianes, 2017). Given the fact that South Sudan ratified the Convention on the Rights of Children recently, and the Constitution of the Country has many provisions on the protection of children, little progress has been reported regarding the protection of children against unlawful attacks and interference.

\section{Methodology}

The study employed a descriptive research design. This is because there was a need to ask questions such as, 'what are the effects of armed conflicts on the right to life of children in Wau, Western Bahr el Ghazal state? 
What are the precipitant causes of recruitment and use of children by parties to the conflict in Wau, Western Bahr el Ghazal State? Both the qualitative and quantitative approaches to research were used. The qualitative approach to research is suitable for non - observable forms of data such as perceptions and feelings of respondents. For quantifiable data, the quantitative approach to research is suitable. The city of Wau is located on the Jur River in Western Bahr el Ghazal State, and it is the second-largest city in the country with an estimated population of 151,320 people (Population Census Council, 2009). The population of Wau is ethnically diverse. Most of the inhabitants are Dinka and Fertit, as the town lies on the tribal boundary between these two peoples. Furthermore, minorities belong to the Luo, Jur Modo/JurBeli, Balanda Boor/BalandaBviri (Al Jazeera, 2017). The Local Community members who were selected for this study constituted the above tribes. Key informants constituted officials from the community and children (directly engaged in the armed conflicts) who played a key role in providing key information of the violation of children's rights by the parties to the conflict. This study had a sample of 405 respondents taken from a total population of 151,320 living in Wau County (Population Census Council, 2009). Two methods of sampling were used. Simple random sampling was used for the quantitative sample comprising of 375 respondents, while purposive sampling was used to determine 30 key informants (who constituted 15 personnel from the local council leaders, NGOs, and UN entities, and 15 children directly engaged in the armed conflicts) for the qualitative sample. To conduct a simple random sample, the researcher used the results of the South Sudan 5th Sudan Population and Housing Census 2008 (Population Census Council, 2009) to generate the list of the households of the five blocks that exist in Wau town so that each household had an equal chance of being drawn during each selection. A random number table was used to select 375 households to respond to the questionnaire. The researchers collected data from both primary and secondary sources. Primary data was obtained from the local community members who were the primary respondents and, additional information was obtained from officials working in various institutions and children (directly engaged in the armed conflicts), who were the key informants for this study. Secondary data was obtained from already published articles on the subject under study. Secondary data was collected by reviewing already published documents related to armed conflicts and violation of children's rights such as newspapers, journals, reports, presentations, magazines, and online publications. This was done to identify the existing information related to the study and to identify the gaps in the literature review. Data collection methods for primary data included Interviews (both Face to Face interviews with the local community and Key Informant Interviews with the key informants - local council and other officials in the community) and Focus Group Discussions (with children directly engaged in the armed conflicts).

The researchers went to the field (the study area) and gathered first-hand information from the respondents. The data collection team constituted a team of 7 people, and fieldwork lasted for one week. Informed consent was sought from the respondents and assent for the children and permission obtained from the relevant authorities in the study area. Other ethical considerations included ensuring the confidentiality of information and identity of respondents and acknowledgment of works of other researchers through referencing. The data collection instruments included; Questionnaire, a Key Informant Interview Guide, and Focus Group Discussion Guide. The questionnaire enabled easier tapping of data from many respondents within a reasonable and limited time frame, at a lesser cost. The questionnaire entailed close-ended questions based on a four - Likert scale of response options (Strongly Disagree, Disagree, Strongly Agree, Agree).

The validity and reliability of the questionnaire were obtained through the following ways. The Content Validity Index (CVI) was used to test the content validity. A team of four experienced researchers in the subject under study were asked to assess the validity of the questions in the questionnaire by ranking them 1 or 2 against the objective or purpose of the study (1-stood for Valid and 2 -stood for Invalid). The CVI was calculated using the following formula.

\section{CVI $=\quad$ Number of Items declared valid by the experienced team} Total number of Items in the Questionnaire

According to Amin (2005), the decision rule to accept the research instrument as valid is when the CVI is greater than 0.7 . Therefore, using the above formula of CVI, the validity of the questionnaire was established.

$$
\mathrm{CVI}=\frac{40}{45} \quad=0.88
$$

The computed CVI is 0.88 and greater than 0.7 , therefore the questionnaire was valid. To test the reliability of the questionnaire, the researchers conducted a pretest of the questionnaire before designing the final version that was used in the field for data collection. The questionnaire was tested with a selected sample of 10 people from another area (outside the study area, Wau). According to Amin (2005), a research instrument is reliable within the range of $0.7-1.0$ (Coefficient of Cronbach's Alpha). 
Cronbach's Results

\begin{tabular}{lcl}
\hline Variables & Number of Items & Cronbach's alpha \\
\hline Armed conflict & 16 & 0.792 \\
Violation of Child's rights & 29 & 0.918 \\
\hline
\end{tabular}

The results show that reliability for the items in the different constructs was attained at the benchmark of $\alpha$ $=0792$ and above. The data was thus deemed appropriate for consideration and analysis.

Key informant interview guides and Focus Group Interview Guides were used to gather additional in-depth data, from open-ended questions, to supplement data gathered from the questionnaire. The two research tools allowed the respondents to freely express themselves and this enabled the researchers to probe further and dig deep into the issue of armed conflicts and their effects on the right to life of children. Questionnaires were checked for completeness by the research team. Quantitative data analysis was based on a total of 357questionnaires that were complete, out of a total of 375 questionnaires considered for the study. The quantitative sample constituted responses from parents/guardians, teachers, health workers, market/street vendors, religious leaders, traditional leaders, and other different categories of local community members. Qualitative data was gathered from Key Informant Interviews and Focus Group Discussions. There were three (3) Focus Group Discussions for purposes of this study, with children (directly engaged in the armed conflicts), and in each focus group, there were 5 children.

Quantitative data were analyzed using the Statistical Package for Social Sciences (SPSS). To examine the armed conflicts and violation of children's rights in Wau, Western Bahr el Ghazal state, data was analyzed using Karl Pearson's approach of coefficient of correlations (Gideon, 2007). Content analysis was used to analyze qualitative data.

\section{Results \\ 4.1 Socio-demographic Characteristics \\ 4.1.1 Gender of Respondents}

The results in Table 1 show that 170 (48\%) of the primary respondents were males and 187 (52\%) were females. This difference in gender ratio had no negative implication on the findings since the focus of the study aimed at obtaining perceptions shared across genders and secondly, these primary respondents were randomly selected, and equal chances of participation to both males and females were given. Key informants included 17 (56.7) males and $13(43.3 \%)$ females. This distribution is attributed to the fact that usually, it is the males who take on leadership positions at the local government level in Wau, and more boys than girls suffer the brunt of armed conflicts as supported by the findings in the reviewed literature for this study.

Table 1. Gender of Respondents

\begin{tabular}{|l|c|c|}
\hline Local Community Members & Frequency & Percent \\
\hline Male & 170 & 48 \\
Female & 187 & 52 \\
Total & $\mathbf{3 5 7}$ & $\mathbf{1 0 0}$ \\
\hline Key Informants & Frequency & Percent \\
\hline Male & 17 & 56.7 \\
Female & 13 & 43.3 \\
Total & $\mathbf{3 0}$ & $\mathbf{1 0 0}$ \\
\hline
\end{tabular}

\subsubsection{Age of Respondents}

The results in Table 2 show that the primary respondents aged between $12-18$ years were $92(25.8 \%)$, those aged between $19-25$ years were $80(22.4 \%), 26-35$ years were $56(15.7 \%), 36-45$ years were $78(21.8 \%)$ and those aged 46 years and above were 51(14.3\%). These statistics indicate that the greatest percentage of the study respondents were 19 years and above. The table below indicates that the majority of respondents were between 12-18 years of age, however, in comparison to the total sample size, this constitutes only $25.8 \%$ compared to the total percentage of adults summed up altogether $(74.2 \%)$. The age of the respondents was considered in this study because the quality of data is influenced by fairness and experience. The involvement of children in this study was equally important given the fact that the study aimed at assessing how their lives have been affected by the armed conflicts. 
Table 2. Age of Respondents

\begin{tabular}{cccc}
\hline Category & Age group (years) & Number & Percent $(\mathrm{N}=357)$ \\
\hline Local Community Members & $12-18$ & 92 & 25.8 \\
& $19-25$ & 80 & 22.4 \\
& $26-35$ & 56 & 15.7 \\
& $36-45$ & 78 & 21.8 \\
Category & 46 and above & 51 & 14.3 \\
\hline Age group (years) & Number & Percent $(\mathrm{N}=30)$ \\
\hline Key Informants & $12-18$ & 15 & 50 \\
& $19-25$ & 02 & 6.7 \\
& $26-35$ & 03 & 10 \\
& $36-45$ & 06 & 20 \\
& 46 and above & 04 & 13.3 \\
\hline
\end{tabular}

\subsubsection{Education of Respondents}

Table 3 below indicates that the majority of the primary respondents $84(23.53 \%)$ were diploma holders, followed by certificate holders $78(21.85 \%)$, degree holders $76(21.29 \%)$, primary education level $74(20.73 \%)$, and lastly, those that had never attended school 45(12.60\%). The education level of participants has been considered significant in this study on the ground that it determines their level of understanding and acquaintance with the research topic. The study found that armed conflicts had affected the education of children (directly engaged in the armed conflicts) who constituted the Key informants in various ways. The study revealed at $8(53.3 \%)$ of those children had never attended school while others $7(46.7 \%)$ ended at primary level and dropped out because most schools were destroyed which made access to education very difficult.

Table 3. Education of Respondents

\begin{tabular}{lll}
\hline Education Level (Local Community Members) & Frequency & Percent $(\mathrm{N}=357)$ \\
\hline None & 45 & 12.60 \\
Primary & 74 & 20.73 \\
Certificate & 78 & 21.85 \\
Diploma & 84 & 23.53 \\
Degree & 76 & 21.29 \\
\hline Education Level (Key Informants) & Frequency & Percent $(\mathrm{N}=30)$ \\
\hline None & 8 & 26.7 \\
Primary & 7 & 23.3 \\
Certificate & 8 & 26.7 \\
Diploma & 5 & 16.7 \\
Degree & 2 & 6.6 \\
\hline
\end{tabular}

4.2. Common Grave Violations Committed Against Children During Armed Conflicts in Wau, Western Bahr el Ghazel State

Violence against children largely depends on the six grave violations committed against children in the situations of armed conflict by parties to the conflict. To assess the effect of armed conflicts on children's rights, the researchers wanted to know first which of the six grave violations are committed most against children in Wau, Western Bahr el Ghazal State.

Table 4. Grave Violations Committed Against Children in Wau

\begin{tabular}{lll}
\hline Grave Violations Committed Against Children & Frequency & Percent \\
\hline Recruitment and use of child soldiers & 68 & 19 \\
Killing and maiming & 34 & 10 \\
Child abduction & 74 & 21 \\
Rape and other forms of sexual violence & 102 & 28 \\
Attacks on schools and hospitals & 46 & 13 \\
Denial of humanitarian access & 33 & 9 \\
\hline Total & 357 & 100 \\
\hline
\end{tabular}


Findings in Table 4 indicate that rape and other forms of sexual violence is the most common grave violation committed against children in Wau, among the six grave violations committed against children in the situations of armed conflict by parties to the conflict. This is observed by $102(28 \%)$ of the responses. This is followed by child abduction constituting 74(21\%) responses, recruitment and use of child soldiers 68(19\%), attacks on schools and hospitals 46(13\%), killing and maiming 34(10\%), and lastly denial of humanitarian access $33(9 \%)$.

In respect to these findings, violation of children's rights is a serious concern in Wau, Western Bahr el Ghazal State. The most-reported violations included sexual violence and child abduction. However, all the six grave violations against children were evoked to be of serious concern. By implication, violence against children in Wau, Western Bahr el Ghazal State is widespread, and respondents were of great concern that the effects of such violations are the biggest threat to the realization of children's rights in Wau, Western Bahr el Ghazal State South Sudan.

\subsection{Precipitant Causes of Recruitment and Use of Children by Parties to the Conflict in Wau, Western Bahr el Ghazal State}

The study explored the reasons why children in Wau, Western Bahr Ghazal joined armed forces and groups. The findings are revealed in Table 5 below.

Table 5. Recruitment and Use of Child Soldiers as a Violation of Children's Rights in Wau

\begin{tabular}{|l|ll|l|}
\hline Recruitment and Use of Child Soldiers & Mean & Std. deviation & Interpretation \\
\hline $\begin{array}{l}\text { Children become part of an armed force or } \\
\text { group because they are abducted and } \\
\text { threatened to take part in the fighting with the } \\
\text { opponents. }\end{array}$ & 3.70 .912 & Very High \\
\hline $\begin{array}{l}\text { Some children join armed force or group as } \\
\text { they are driven by poverty and compelled to } \\
\text { generate income for their families whilst } \\
\text { others associate themselves for survival or to } \\
\text { protect their communities. }\end{array}$ & 3.96 & .998 & Very High \\
\hline $\begin{array}{l}\text { Children are recruited in the army because } \\
\text { they are cheap and not paid salaries. }\end{array}$ & 2.78 & .789 & high \\
\hline $\begin{array}{l}\text { Children are recruited by armed forces } \\
\text { because they are less visible to enemies. }\end{array}$ & 2.39 & .548 & High \\
\hline $\begin{array}{l}\text { Children are being used in the army because } \\
\text { they are easy to manipulate and obey orders } \\
\text { by the commanders. }\end{array}$ & 2.21 & .824 & High \\
\hline Average mean & $\mathbf{3 . 0 0 8}$ & $\mathbf{8 0 9}$ & \\
\hline
\end{tabular}

Findings in Table 5 above agree with the earlier reviewed reports by the UN bodies and Kate (2015) in her study on the fragility and state relations in South Sudan, that there are many reasons why children are associated with armed forces or groups. The results in Table 5 revealed that some children join an armed force or group as they are driven by poverty and compelled to generate income for their families whilst others associated themselves with survival or to protect their communities (Mean=3.96, std. dev .998). This was the most precipitant cause of recruitment and use of children by parties to the conflict in Wau. The findings also revealed that children become part of an armed force or group because they are abducted and threatened to take part in the fighting with the opponents as shown by the mean counts of 3.70 (std. dev. .912) which was very high as well. According to the findings, children are also recruited in the army considering them to be cheap to maintain and they take direct part in active combat though not paid (Mean $=2.78$, std. dev. .789), meaning that parties involved in fighting perceive children as a cost-effective mechanism to use, to achieve their missions. The growing number of children victimized in armed conflicts is not only a violation of their rights but a threat to the future generation as many of these children do not go away without psychosocial challenges.

A respondent working with "Kids Alive International" - a Local NGO highlighted that:

“...on average out of every 10 children, 5 or 7 children as young as 15 years old, are rescued or fled from being recruited by the warring parties. Some of these children have been raised in combat camps and therefore most likely or forced to become child soldiers either to protect their families or even revenge on parties who harmed them... ". (NGO official, Key Informant, NGO official, Wau)

According to the findings, it was also established that children are recruited by armed forces because they are small objects that cannot easily be seen by the enemies due to their small bodies (Mean $=2.39$, std. dev. .548). This means that children have been used as a tool that is less visible to enemies and therefore 
manipulated by the perpetrators to commit crimes as per their commanders' orders to attack individuals. The FGD with children directly engaged in the armed conflicts revealed the following:

"Sometimes we are told to place and or throw explosives at certain points. We can hide under trees, crawl in the bushes and sometimes walk to the different enemy camps and advance the agenda of our commanders. I remember when my friend was told to detonate a bomb at one camp and he died as well in the process". (Boy, 17 years, during the FGDs with children directly engaged in the armed conflicts, Wau)

Based on the findings, some progress has been made to resolve conflicts in South Sudan, but several children continue to suffer human rights violations although perpetrators, even when identified have not been brought to courts of law for justice towards children.

In addition, results indicated that children are being used as child soldiers because they are easy to manipulate and obey orders by the commanders (Mean $=2.21$, Std. dev .824). This means that respecting and the understanding of rights by both victims and perpetrators is either miscalculated or undermined because it is not generally considered necessary that a right should be understood by the holder of that right but must be recognized on behalf of another. In addition, it seems that little is known by some of the key stakeholders in children protection about national laws of South Sudan as was noticed during interviews with a UN Peacekeeper who asserted that:

"...I do not have enough insight about the civil and criminal penal codes on the protection of children, but I know South Sudan is a signatory to the Convention on the Rights of Children......". (Key Informant, UN Peacekeeper, Wau)

The Pearson's correlation coefficient in table 6 further explains armed conflicts and the recruitment of children as child soldiers in Wau, Western Bahr el Ghazal State.

Table 6. Pearson's Correlation Test Results on Levels of Significance of Armed Conflicts and Recruitment of Children as Child Soldiers

\begin{tabular}{|c|c|c|c|}
\hline & Items & & $\begin{array}{l}\text { Recruitment of } \\
\text { children in the } \\
\text { army }\end{array}$ \\
\hline \multirow{5}{*}{$\begin{array}{l}\text { Armed } \\
\text { conflict }\end{array}$} & $\begin{array}{l}\text { Parties involved in the armed } \\
\text { conflicts recruit and use children in } \\
\text { active combats. }\end{array}$ & $\begin{array}{l}\text { Pearson's correlation } \\
\text { Sig. (2 tailed) }\end{array}$ & $\begin{array}{r}.766^{* *} \\
.000\end{array}$ \\
\hline & $\begin{array}{l}\text { Children are not only used in active } \\
\text { combats but also used in risky } \\
\text { operations like looting. }\end{array}$ & $\begin{array}{l}\text { Pearson's correlation } \\
\text { Sig. (2 tailed) }\end{array}$ & $\begin{array}{r}.262^{* *} \\
.000\end{array}$ \\
\hline & $\begin{array}{l}\text { Children are recruited in the army } \\
\text { because they are cheap and not paid } \\
\text { salaries. }\end{array}$ & $\begin{array}{l}\text { Pearson's correlation } \\
\text { Sig. (2 tailed) }\end{array}$ & $\begin{array}{r}.109 * * \\
.000\end{array}$ \\
\hline & $\begin{array}{l}\text { Children are recruited by armed } \\
\text { forces because they are less visible to } \\
\text { enemies. }\end{array}$ & $\begin{array}{l}\text { Pearson's correlation } \\
\text { Sig. (2 tailed) }\end{array}$ & $\begin{array}{r}.235 * * \\
.000\end{array}$ \\
\hline & $\begin{array}{l}\text { Children are being used in the army } \\
\text { because they are easy to manipulate } \\
\text { and obey orders by the commanders }\end{array}$ & $\begin{array}{l}\text { Pearson's correlation } \\
\text { Sig. (2 tailed) }\end{array}$ & $\begin{array}{r}.312^{* *} \\
.000\end{array}$ \\
\hline
\end{tabular}

The statistics in Table 8 are interpreted as follows: The ( $\mathrm{r}$ statistics $=0.766^{* *}$ ) indicates a strong and positive relationship between armed conflict and the use of children in active combats. The $r$ statistics $0.262 * *$ also shows that there is a positive relationship between armed conflicts and the use of children not only inactive combats but also in other risky operations like looting. Similarly, there was a weak but still positive correlation between armed conflicts and recruitment of children in the army because they are cheap and not paid $(\mathrm{r}=$ $\left.0.109^{* *}\right)$. However, a strong positive relationship was noted that children are used because they are less visible to the enemies $\left(\mathrm{r}=.235^{* *}\right)$ and because they are easy to manipulate $\left(\mathrm{r}=312^{* *}\right)$. Meaning that parties involved in the fighting have less interest in protecting children but rather manipulating them in favor of fulfilling their ambitions. 
4.3. Effects of Armed Conflicts on the Right to Life of Children in Wau, Western Bahr el Ghazal State

The study also wanted to assess the effect of armed conflicts on the right to life of children in Wau, Western Bahr el Ghazal State. Under this section, the study assessed how armed conflicts have denied children a right to life. This was manifested in the assessment of items related to killings and maiming of children.

Table 7. Killings and maiming as a violation of children's rights

\begin{tabular}{|l|l|l|l|}
\hline Killing and Maiming & Mean & $\begin{array}{l}\text { Std. } \\
\text { deviation }\end{array}$ & Interpretation \\
\hline $\begin{array}{l}\text { Children are the major causalities to landmines and } \\
\text { other explosives. }\end{array}$ & 3.64 & .948 & Very High \\
\hline $\begin{array}{l}\text { Unexploded landmines are common, and children } \\
\text { are victims due to their playful nature. }\end{array}$ & 3.39 & .878 & Very High \\
\hline $\begin{array}{l}\text { Landmines and other explosives that have not been } \\
\text { successfully removed from the conflict zones have } \\
\text { led to the death of many children. }\end{array}$ & 3.63 & .976 & Very high \\
\hline $\begin{array}{l}\text { Unspecified number of children got killed and some } \\
\text { injured during the conflicts in Wau. }\end{array}$ & 2.78 & .789 & High \\
\hline $\begin{array}{l}\text { Children are being killed based on identity as } \\
\text { members of an ethnic group. }\end{array}$ & 2.68 & .678 & High \\
\hline \begin{tabular}{l} 
Average mean \\
\hline
\end{tabular} & $\mathbf{3 . 2 2 4}$ & .917 & Very High \\
\hline
\end{tabular}

Based on the results in Table 7, children are major causalities to landmines and other explosives as counted by the mean value of 3.64 (std. dev .948) interpreted as very high on the Likert scale, implying that even though these landmines may primarily be targeting other groups of people, children have fallen victims. Results further indicated that unexploded landmines are common, and children are victims because of their playful nature (Mean=3.39, std. dev .878) entailing that the vulnerable nature of children in many cases exposes them to dangerous effects of armed conflicts. One official from a local NGO had this to say:

"...to tell you the truth, armed conflicts have claimed the lives of not only adult civilians but a significant number of innocent children have been killed, many young boys and girls in this area are no more, we have lost many children, help is needed to help us stop this problem as soon as possible... ".(Key Informant, NGO official, Wau)

The above revelation clearly shows that children have been killed during armed conflicts. This is not a new phenomenon although what worries me is that even after going through the waves of the conflicts, many children continue to die due to unremoved explosives. Results in Table 7 showed that children are at high risk of being killed by landmines and other explosives that have not been successfully removed from the conflict zones (mean $=3.63$, std. dev .976). Agree with a scholar

Further still, the study revealed that an unspecified number of children got killed and some injured during conflicts as showed by the mean value of 2.78 , (Std. dev .789) an implication that even though estimates are available, the exact number of children affected by the conflict in Wau, Western Bahr el Ghazal State is hard to establish. The findings also revealed that children are being killed based on identity as members of an ethnic group (mean=2.68, std. dev.678).

In their own words, children directly engaged in the armed conflicts had the following to lament, in the three FGDs that were conducted with this specific category during data collection.

"We have experienced many challenges like hiding in the bush, I saw 3 girls shot dead, my aunt killed and one time in the night my friend was bitten by a snake. Seeing dead bodies is my worse experience, my brother was killed, and my sister was abducted. My uncle told me that my mother was raped, and my father killed. Uhmmm., me if I get a chance to see the man who killed my father, I will also kill him! I am now the caretaker of my 2 surviving young sisters aged 5 and 7 years. I get scared whenever I hear any burst sound, I just feel that someone has been killed. I don't want to lose another family member nor do I want to die, because I love to be with my sisters all the time. I don't want anything bad to happen to them. "(Boy, 17 years, during the FGD with children directly engaged in the armed conflicts, Wau) 
"We were running from our village and found a group of armed men, I was with my mother, and sisters and two brothers. One of my brothers was taken away until now we have not seen him. For us we were rescued by the UN peacekeepers however after a few weeks my other brother died, he could not survive the wounds when they attacked us. I saw men pushing my sister on the ground and she now has a 3-year-old child. "(Boy, 17 years, during the FGD with children directly engaged in the armed conflicts, Wau)

"We are experiencing hard living conditions. Me I do not want to think about war because up to now, I cannot sleep whenever I lie down, all I can see is dead bodies in the compound. I think even Djugo (she pointed at her colleague) is suffering from the same problem because we share the same bed, but she always wakes up shouting".(Girl, 15 years, during the FGD with children directly engaged in the armed conflicts, Wau)

"Every time I remember my sister who was taken away by masked men, I hide myself and start crying, it keeps going and coming back... "(Girl,

13 years, during the FGD with children directly engaged in the armed conflicts, Wau)

“... I miss being with my family, we were all displaced. Now I have a baby because of rape, sometimes I feel like killing my child and run away because every time am alone, I remember the pain when those men raped me, it is even more painful because I cannot see my mother... "(Girl, 18 years, during the FGD with children directly engaged in the armed conflicts, Wau)

"It is very hurtful that we are now beggars. My dream was to study hard and get good grades. I wanted to become a nurse and help my family and the community to treat them but since the fighting, I have lost hope because we are now very poor, and my parents cannot afford to take me to school. I am now working with them at the rich man's farm to get food. I want to go back to my village in Tambura with my parents because we used to get everything we want from there. "(Girl, 17 years, during the FGD with children directly engaged in the armed conflicts, Wau)

"Our house was burnt down; I don't even feel like going back to my village because now am a school dropout with no family, so I have to find means of survival. Although the UN sometimes supports us, I have to learn to live on my own now". (Boy, 16 years, during the FGD with children directly engaged in the armed conflicts, Wau)

"Sexual harassment is the worst thing I have seen happening repeatedly in the camp where I stay. Uhmmmm.... (sighs)......... (cries)......." (Girl, 16 years, during the FGD with children directly engaged in the armed conflicts, Wau)

Judging from the children's narratives, it is evident that as a result of armed conflicts, children have experienced physical and psychological/emotional abuse which have led to the violation of their rights, such as suffering from fear, trauma, loss of life, loss of shelter, rape, dropping out of school, lack of access to food, sexual abuse and abductions and loss of parents

The findings of this study agree with Breadcook (2013) who revealed that during armed conflict situations, there is a tremendous loss of lives, destruction of property, mass killings of individuals, and sexual violence among other human rights infringements. In 2006, the UN General Assembly also pointed out that in the last decade, more than two million children worldwide have been killed in situations of armed conflict, six million children have been permanently disabled or injured, more than two hundred and fifty thousand children have continued to be exploited as child soldiers, between eight thousand and ten thousand children have been killed or maimed every year as a result of landmines and more than 14 million children have been forcibly displaced within and outside their home countries since 2010 (UNICEF, 2019).

4.3.1 Pearson's correlation coefficients on armed conflicts and killing and maiming of children

Having described the extent of killing children in Wau, Western Bahr el Ghazal state, the relationship on how this violation of children's rights is influenced by armed conflicts was verified using Pearson's correlation coefficient as presented in Table 8 . 
Table 8. Pearson's correlation test results on levels of significance of armed conflicts and killing and maiming of children in Wau

\begin{tabular}{|c|c|c|c|}
\hline & & & $\begin{array}{r}\text { Killing an } \\
\text { maiming of childre }\end{array}$ \\
\hline \multirow{9}{*}{$\begin{array}{l}\text { Armed } \\
\text { conflict }\end{array}$} & Children are the major causalities to & Pearson's correlation & $.645^{* *}$ \\
\hline & landmines and other explosives. & Sig. (2 tailed) & .000 \\
\hline & children are victims to unremoved & Pearson's correlation & $.545^{* *}$ \\
\hline & landmines due to their playful nature & Sig. (2 tailed) & .000 \\
\hline & Landmines and other explosives that & Pearson's correlation & $.709 * *$ \\
\hline & $\begin{array}{l}\text { have not been successfully removed } \\
\text { from the conflict zones have led to }\end{array}$ & Sig. (2 tailed) & .000 \\
\hline & the death of many children & & \\
\hline & Children are being killed based on & Pearson's correlation & $.324^{* *}$ \\
\hline & $\begin{array}{l}\text { identity as members of an ethnic } \\
\text { group }\end{array}$ & Sig. (2 tailed) & .000 \\
\hline
\end{tabular}

** Correlation is significant at the 0.01 level (2-tailed).

The statistics in Table 8 above are interpreted as follows: The $r$ statistics $0.645^{* *}$ denotes a positive moderate relationship while $\mathrm{p}<0.001$, indicates that the coefficient is significantly different from 0 . This means, there was a significantly positive relationship between armed conflicts and violation of children's right to life, killing of children as major causalities to landmines and other explosives. Thus, a decrease in the use of landmines and explosives leads to a decrease in the number of children killed and vice versa.

Coefficient, $r=0.709^{* *}$ connotes a strongly positive relationship. $\mathrm{p}<0.001$, signifies that $\mathrm{r}$ is significantly different from 0 . In that case, there was a significantly positive relationship between armed conflict and the number of children being victims to unremoved landmines due to their playful nature in the study area. This infers that the higher the number of unremoved landmines, the higher chances of more children becoming victims should to such landmines, if not removed.

Correlation coefficient $r=0.324^{* *}$ shows a weak but positive relationship, and $p<0.001$, means that $r$ is significantly different from 0 . It can be interpreted that, there was a positive relationship between armed conflicts and the number of children being killed based on identity as members of a particular ethnic group in Wau, Western Bahr el Ghazal State implying that children are killed but most likely not based on their ethnic lines. However, this can be true if a group of children is settled in a specified area.

\section{Discussion}

According to the findings, the respondents were mostly adults. These are considered mature and able to understand the purpose of the study. Both males and females participated in the study, in almost equal numbers, which enabled the inclusion of all potential respondents for the study.Most of the respondents had acquired some form of education which meant that they could easily provide the relevant information required for the study. The findings revealed the most common grave violations committed against children in Wau. Many children in Wau suffer from rape and other forms of sexual violence.It is hard to generate evidence on rape and other forms of sexual violence in Wau since there is no evidence of surveillance cameras in most of the places where the armed groups and armed forces operate. Also, due to the high levels of poverty in the area, many respondents cannot meet the cost of medical review/examination to generate evidence of rape and other forms of sexual violence. Children in Wau are also abducted and used as child soldiers. The FGDs with children revealed that many of them have lost one or two of their parents and lack protection from an adult figure. This easily exposes them to the hands of the abductors and judging from the situation at hand, if it is wartime (fighting), soldiering becomes the perfect fit.Other children are killed, denied humanitarian access, and experience attacks on schools and hospitals. These findings on the common grave violations experienced by children in Wau are in agreement with UNICEF (2016), Kelly, Branham and Decker (2016), and Beber and Blattman (2013). The findings in table 
5revealed that the greatest number of children in Wau join armed forces or groups as they are driven by poverty and compelled to generate income for their families while others associate themselves with survival or to protect their communities. This was also captured in some of the verbatim quotations for children in the FGDs, where survival is a compelling factor in engaging in armed conflicts. It is generally believed that wars destroy properties, loss of lives, and cause displacement of people thus negatively affecting the economy. Hence, the circulation of money and other financial resources will be limited causing worry among people and therefore, they can easily engage in any form of activity that gives them something for the pocket. Findings in Table 5 also confirm the reports by UNICEF (2016), Kelly, Branham and Decker (2016), and Beber and Blattman (2013), that children become part of an armed force or group because they are abducted and threatened to take part in the fighting to fulfill and achieve the ambitions of the armed group or force. The findings further revealed that children in Wau are recruited into the army simply because they are cheap and not paid salaries. The cost of feeding and clothing children is low compared to adults. The findings also revealed that children are recruited by armed forces or groups because they have small bodies that cannot be easily be seen by the enemies. This means that children have been used as a weapon of destruction that is less visible to enemies of the armed group or force, they belong to. The findings also revealed that children are being used in the army because they are easy to manipulate and obey orders by the commanders. Children can easily succumb to false promises than adults. Children are easier to recruit than adults. There is no need to negotiate with a child. A child can work on unquestionable instructions compared to an adult, that is why children are often versatile enough to serve many roles in the army, and therefore, their preference by the army commanders. The findings on causes of recruitment and use of children in armed forces or groups signify that the respect of the rights of children is undermined by the armed forces or groups who use children. The findings also further indicate that the understanding of the rights of children is misjudged because it is not only necessary for the right to be understood by the holder (in this case the children) but also, must be recognized on behalf of another. There is therefore much need for sensitization and awareness in the country on the rights and protection of children.Evidence from the study findings without any doubt confirms that children in Wau, Western Bahr el Ghazal State are being killed and suffered from all the six grave violations against their rights as a result of armed conflicts. The findings in table 7 and 8 indicate that children have been killed and injured as a result of armed conflicts. Children have been raped and have experienced other forms of sexual violence, they have dropped out of school, they have been traumatized, suffered hunger, ill health, and other problems as a result of armed conflicts. Many of these experiences of children were captured in their narratives (verbatim quotations) under the different focus group discussions. All the above effects pose a threat to the right to life of children. The biggest threat is that the country is still fragile and violence by some communities is an acceptable norm to communicate/deliver a message or settle issues. This inhibits reporting of human rights violations, affects law enforcement, and fuels further violations to humanity. The country is making progress to resolve conflicts through several peace talks, but several children continue to suffer human rights violations which is a threat to the future progress of the country.

\section{Conclusion}

The violation of children's rights in Wau is to a large extent persistent due to armed conflicts. Armed conflicts, which are fueled by either tribal or political tensions have had many adverse effects on the rights of children. The right to life of children in Wau has been seriously threatened as children have been killed, abducted, and sexually abused, among other physical and psychological challenges/problems. The effects of the armed conflicts on children are further exacerbated by the limited access to services such as justice, due to poor implementation of laws and policies on children protection. Children are suffering within their communities largely due to a lack of enough capacity to protect them. This puts many children vulnerable to the six grave violations committed against children during armed conflicts, with rape and other forms of sexual violence, abduction and recruitment, and use of child soldiers most prevalent in Wau, among other grave violations. The study revealed that children are recruited and used in armed forces or groups due to many reasons. Most poor countries that have plunged into unending wars have been associated with high levels of poverty. South Sudan is a party to unending wars and therefore, the high levels of poverty experienced by its citizens. Evidence from the findings proved that many children in Wau joined armed forces or groups as they are driven by poverty and compelled to generate income for their families while others associate themselves with survival or to protect their communities.

\section{Recommendations}

Children protection is very crucial for any country as it advances its development agenda(s). Therefore, children rights abuses should be handled by all the relevant stakeholders in the country. The Government, International, Local NGOs, the Private Sector, and Civil society should ensure that all national laws and policies on the protection of children are effectively implemented and the ratified international instruments or optional protocols 
are adhered to. More concrete mechanisms regarding the protection of children in situations of armed conflicts can be sought from best practices elsewhere. There should be avenues in place to beef up the budget on children protection and to ensure accountability of child protection implementations or activities. Sensitization and awareness of children's rights and protection should be continuous.

\section{References}

Al Jazeera (2017). "South Sudan: Civilians killed in Wau fighting," [online] Available: https://www.aljazeera.com/news/2017/4/10/south-sudan-civilians-killed-in-wau-fighting (April 18, 2021)

Amin, M. E. (2005). Social Science Research Conception, Methodology and Analysis. Makerere University Press, Kampala.

Beber, B., \&Blattman, C. (2013). "The Logic of Child Soldiering and Coercion", International Organization, 67(1), 65-104. doi:10.1017/S0020818312000409

Breadcook, B. H. (2013). "Forced Wives as Victims and Perpetrators of War Violence in Transitional JusticeProcesses," [online] Available: https://www.gla.ac.uk/media/Media_307343_smxx.pdf (June 28, 2021)

Deng, K. (2018). "Child Protection in Emergencies Desk Review”, Child Protection Working Group.

Doek, J. E. (2014). Child Well-Being: Children's Rights Perspective. In: Ben-Arieh A., Casas F., Frønes I., Korbin J. (eds) Handbook of Child Well-Being. Springer, Dordrecht.

Ensor, M. O. (2013). "Participation under Fire: dilemmas of reintegrating child soldiers involved in South Sudan's armed conflict," Global Studies of Childhood, 3(2).

Ferdinand V. H. L. (2014). "South Sudan Protection Cluster Macro Analysis of Conflict in South Sudan," [Online] Available:https://www.humanitarianresponse.info/es/operations/south-sudan/document/macroanalysis-conflict-south-sudan-august-2014 (July 12, 2021)

Harju, A.K. (2013). "Violations of Children's Rights in Armed Conflicts. International Treaties, Observations by Peacekeepers and Crisis Management Training in Finland," [Online] Available at: https://www.doria.fi/bitstream/handle/10024/96713/harju_anna.pdf?sequence=2 (September 22, 2021)

Human Rights Watch, (2012). "Q\&A on Joseph Kony and the Lord's Resistance Army," [Online] Available at: http://www.hrw.org/news/2012/03/21/qa-joseph-kony-and-lords-resistance-army. (August 30, 2021)

Gideon, R. A. (2007). "The Correlation Coefficients," Journal of Modern Applied Statistical Methods, 6(2), $517-$ 529.

Kate, A. K. (2015). "Fragility and state-society relations in South Sudan," Africa Centre for Strategic Studies Research Paper No.4, September $30^{\text {th }}$.

Kelly, J., Branham, L. \& Decker, M.R. (2016).“Abducted children and youth in Lord's Resistance Army in Northeastern Democratic Republic of the Congo (DRC): mechanisms of indoctrination and control," Confl Health, 10(11). https://doi.org/10.1186/s13031-016-0078-5

Kohrt, B. A., Yang, M., Rai, S., Bhardwaj, A., Tol, W. A., \&Jordans, M. J. (2016). "Recruitment of child soldiers in Nepal: Mental health status and risk factors for voluntary participation of youth in armed groups," Peace and conflict: journal of peace psychology: the journal of the Division of Peace Psychology of the American Psychological Association, 22(3), 208-216. https://doi.org/10.1037/pac0000170

Liebling-Kalifani, H. et al. (2010). "Women War Survivors of the 1989-2003 Conflict in Liberia: The Impact of Sexualand Gender-Based Violence," Journal of International Women's Studies, 12(1), 1-21.

Machel, G. (1996). "Promotion and protection of the rights of the children: Impact of armed conflict on children," Note by the Secretary-General (Resolution No. A/51/306). [Online] Available at: http://www.unicef.org/graca/women.htm (March 28, 2021)

Machel, G. (2000). "The Impact of Armed Conflict on Children. A critical review of progress made and obstacles encountered in increasing protection for war-affected children," [Online] Available at: http://www.waraffectedchildren.com/machel-e.asp (August 20, 2021)

Mezmur, D. (2019). "Taking measures without taking measurements? An insider's reflections on monitoring the implementation of the African Children's Charter in a changing context of armed conflict," IRRC No. 911.

Nyagoah, T. P. (2018). "Women line up for food rations at a distribution site in Bentiu, South Sudan," Human Rights Watch.

Parker, M., Fergus, C.A., Brown, C. et al. (2021). "Legacies of humanitarian neglect: long term experiences of children who returned from the Lord's Resistance Army in Uganda," Confl Health, 15(43). https://doi.org/10.1186/s13031-021-00374-5

Perianes, A. (2017). "The Unbearable Situation of Children in Armed Conflicts around the world," [Online] Available: https://impakter.com/children-armed-conflicts-around-world/ (May 15, 2021)

Population Census Council (2009). "5TH Sudan Population and Housing Census - 2008," [Online] Available at: file:///C:/Users/HP-PC/Desktop/5th_sudan_census26_april_2009.pdf(August 13, 2021)

Roos, H. (2019). "Children and armed conflict: looking at the future and learning from the past," Third World 
Quarterly, 40(1): 74-91. doi: 10.1080/01436597.2018.1552131

Stewart, J. (2003). "Towards a single definition of armed conflict in international humanitarian law: A critique of internationalized armed conflict," Revue Internationale De La Croix-Rouge/International Review of the Red cross, 85(850): 313-350. Doi:10.1017/S0035336100115199

Tamazuj Radio. (2017). "NDM condemns targeted killings in Wau town,"[Online] Available at: https://radiotamazuj.org/en/news/article/ndm-condemns-targeted-killings-in-wau-town (August 19, 2021)

U.N. Security Council (2015). Interim report of the Panel of Experts on South Sudan established pursuant to Security Council resolution 2206 (2015), U.N. Document S/2015/656.

UNICEF (2019). "2019 concludes a 'deadly decade' for children in conflict, with more than 170,000 grave violations verified since 2010," [Online] Available at: https://www.unicef.org/press-releases/2019concludes-deadly-decade-children-conflict-more-170000-grave-violations-verified (September 21, 2021)

UNICEF (2016). "Hundreds of Children Recruited by Armed Groups in South Sudan, as Violations against Women and Children Increase," [Online] Available at: https://www.unicef.org/press-releases/hundredschildren-recruited-armed-groups-south-sudan-violations-against-women-and (September 21, 2021)

UNICEF (2015). "Situation Assessment of Children and Women in South Sudan," [Online] Available at: https://www.28toomany.org/static/media/uploads/Country\%20Research\%20and\%20Resources/South\%20S udan/unicef_south_sudan_situation_assessment_of_children_and_women_2015.pdf (September 21, 2021)

United Nations Office of the Special Representative to the Secretary-General for Children and Armed Conflict. "Child Recruitment and Use, " https://childrenandarmedconflict.un.org/six-grave-violations/child-soldiers/.

World Vision (2019). "South Sudan Conflict, Hunger: Facts, FAQs, and How to Help," [Online] Available at: https://www.worldvision.org/refugees-news-stories/south-sudan-conflict-facts (September 21, 2021)

Young, J. (2012). The Fate of Sudan: The origins and consequences of a flawed peace process. (revised edition). Bloomsbury Publishing 